\title{
Rozumowanie przez analogie oparte na materiale geometrycznym u uczniów niewidomych
}

\begin{abstract}
Izabella Kucharczyk, Rozumowanie przez analogie oparte na materiale geometrycznym u uczniów niewidomych [Analogical reasoning based on geometric material in blind pupils]. Interdyscyplinarne Konteksty Pedagogiki Specjalnej, nr 21, Poznań 2018. Pp. 227-245. Adam Mickiewicz University Press. ISSN 2300-391X. DOI: https://doi.org/10.14746/ikps.2018.21.12

Analogical reasoning constitutes one of the ways the blind get to know the world; it enriches information and influences thinking.

The purpose of the article is the presentation of results of research on reasoning using geometric analogies in blind pupils aged 10,12 and 14. The study encompassed a group of 63 blind pupils and 63 seeing pupils. The study used the twelve series B matrices from the Progressive Matrices of John C. Raven. A detailed analysis of the dependencies between the variables permitted the determination of differences between groups of pupils in terms of reasoning using geometric analogies.
\end{abstract}

KEY WORDS: analogical reasoning, blind pupils, geometric analogies

\section{Wprowadzenie}

Analogia jest pojęciem używanym w różnych codziennych sytuacjach. Gdyby człowieka pozbawiono możliwości korzystania $\mathrm{z}$ analogii, najprawdopodobniej nie poradziłby sobie z przyswajaniem nowej wiedzy. 


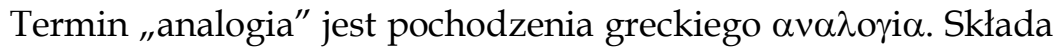
się z przysłówka an, ana $(\alpha v, \alpha v \alpha)$ i odnosi się do stopnia powielenia, np. dwukrotnie, trzykrotnie. Drugi składnik tego pojęcia to rzeczownik logos $(\lambda \circ \gamma \circ \xi)$, pochodzący od czasownika legin $(\lambda \varepsilon \varepsilon \gamma \varepsilon i v)$, co oznacza składać, mówić. Etymologicznie pojęcie "analogia” jest stanem odnoszącym się do bytowania określonej rzeczy lub też dowodzeniem o niej.

Przeglądu literatury przedmiotu na temat różnych ujęć pojęcia "analogia” dokonali Zdzisław Chlewiński, Andrzej Falkowski i Piotr Francuz ${ }^{1}$. Znane są dwa podejścia odnośnie definiowania tego terminu. Pierwsze to podejście strukturalne, inaczej syntaktyczne, zakładające, że analogia jest czymś równoważącym pomiędzy dwoma obiektami lub zdarzeniami. Pozwala ona na analizę relacji pomiędzy wybranymi elementami jakiegoś zdarzenia. Ta analiza może odnosić się do elementów dostępnych na drodze percepcji bądź też składowych danego zdarzenia, które są niedostępne bezpośrednio naszemu poznaniu. Drugie podejście - funkcjonalne, inaczej pragmatyczne, wyjaśnia "analogię" w nieco odmienny sposób. Analogia, zdaniem zwolenników tego ujęcia, odnosi się przede wszystkim do szukania związków pomiędzy elementami zewnętrznymi, wychodzącymi poza zakres dotyczący badanego zdarzenia. Proces analogizowania, czyli porównywania zdarzeń, jest możliwy w momencie, kiedy pojawia się gotowość do myślenia w kategoriach przyczynowo skutkowych.

Zdaniem Edwarda Nęcki, Jarosława Orzechowskiego i Błażeja Szymury ${ }^{2}$ analogia jest pewnym transferem pomiędzy różnymi dziedzinami nauki. Transfer może być pozytywny (kiedy jednostka pogłębia wiedzę i wykorzystuje różne techniki, aby rozwiązać napotkany problem) lub też negatywny (w tym przypadku zastosowanie podobnych technik $\mathrm{w}$ zbliżonych sytuacjach problemowych jest mało skuteczne).

1 Z. Chlewiński, A. Falkowski, P. Francuz, Wnioskowanie przez analogię w procesach kategoryzacji, Wydawnictwo Towarzystwo Naukowe KUL, Lublin 1995, s. 25-38.

2 E. Nęcka, J. Orzechowski, B. Szymura, Psychologia poznawcza, Wydawnictwo Naukowe PWN, Warszawa 2006, s. 474-478. 
Analogia jest podstawą do wyciągania pewnych wniosków, do łączenia ze sobą danych w poszczególne podklasy. Dzięki procesom analogii, na podstawie posiadanych informacji o danym przedmiocie, możliwe jest przypisywanie jego cech innym przedmiotom. Analogia może dotyczyć semiotyki oraz metodologii. Z punktu widzenia metodologii jest ona oceniana jako podstawowa teoria będącą punktem wyjścia dla niektórych rozumowań lub teorii modeli3 ${ }^{3}$.

Należy podkreślić, że terminy „analogia” i „rozumowanie przez analogie" nie są terminami jednoznacznymi.

Rozumowanie przez analogie, jak podaje Tadeusz Kwiatkowski:

jest to rozumowanie, w którym, mając w jednym (lub więcej) zaobserwowanym przypadku pewien układ elementów, w innym zaś fragment takiego układu, dochodzimy do stwierdzenia, jak ten fragment uzupełnia się do całości układu ${ }^{4}$.

Z kolei Adam Biela ${ }^{5}$ podaje trzy główne cele rozumowania przez analogię:

1) rozumowanie przez analogie może być wykorzystane do wzbogacenia posiadanej wiedzy,

2) rozumowanie przez analogie pozwala na określenie relacji pomiędzy elementami,

3) rozumowanie przez analogie zwiększa prawdopodobieństwo, że dana konkluzja jest prawdziwa.

\section{Rozumowanie przez analogie u uczniów niewidomych}

Badań na temat rozumowania przez analogie u uczniów z niepełnosprawnością wzroku jest stosunkowo niewiele. Bogdan Pietru-

${ }^{3}$ J. Przybyłowski, O pewnej interpretacji wnioskowania przez analogie, [w:] Logiczne podstawy rozumowań, cz. II, red. L. Kostro, J. Przybyłowski, Wydawnictwo, Uniwersytet Gdański, Gdański 1997, s. 28-39.

4 T. Kwiatkowski, Logika ogólna, Wydawnictwo UMCS, Lublin 1992, s. 303.

${ }^{5}$ A. Biela, Psychologiczne podstawy wnioskowania przez analogie, Wydawnictwo PWN, Warszawa 1989, s. 19-39. 
lewicz ${ }^{6}$ przeprowadził eksperymenty wśród 60 osób niewidomych w wieku szkolnym (III, V i VII klasa szkoły podstawowej). Wychodził on z założenia, że osoby niewidome, posługując się od najmłodszych lat analogią, zdobywają umiejętności coraz lepszego jej zastosowania, nawet $\mathrm{w}$ sytuacjach całkowicie dla siebie nowych. Eksperymenty Bogdana Pietrulewicza dotyczyły analogii opartych na materiale semantycznym (relacje część - całość, relacja przeciwieństwa, relacja przyczynowo skutkowa), bazujących na materiale liczbowym oraz analogii geometrycznych. Główną hipotezą było stwierdzenie, że zdolność rozumowania przez analogie rozwija się $\mathrm{w}$ takim samym stopniu, jak $\mathrm{w}$ przypadku osób widzących. W zakresie analogii opartych na materiale figuralnym lepiej wypadają osoby widzące, wykonujące zadania w zakresie percepcji wzrokowej, jako kolejni zaklasyfikowali się niewidomi, wykonujący te same zadania co widzący, ale w wersji dotykowej. Najniższe wyniki osiągnęli niewidomi rozwiązujący zadania $\mathrm{w}$ wersji dotykowej.

Zofia Sękowska ${ }^{7} \mathrm{w}$ swoich badaniach nad rozumowaniem przez analogie podkreśliła, jak wielkie jest znaczenie analogii, zwłaszcza przy ujmowaniu zewnętrznych cech określonych przedmiotów, takich jak: wielkość, barwa, kształt. Są to cechy niedostępne niewidomym. Zdaniem Zofii Sękowskiej osoby niewidome wykorzystują analogie przy poznawaniu prostych, mało rozbudowanych przedmiotów, a jest to możliwe dzięki posiadaniu ogólnych informacji na dany temat. Stosunkowo rzadko osoby niewidome posługują się analogiami odnośnie wielkości przedmiotów. Inną zaletą stosowania analogii jest wykorzystywanie ich do nazywania doznań zmysłowych czy emocjonalnych oraz do tworzenia wyobrażeń surogatowych. Zdaniem badaczki wyobrażenia surogatowe to:

${ }^{6}$ B. Pietrulewicz, Rozwój rozumowanie przez analogię u dzieci niewidomych, Wydawnictwo PAN, Komitet Nauk Psychologicznych, Zakład Narodowy Ossolińskich, Wrocław, Kraków, Gdańsk, Łódź 1983, s. 82-95.

7 Z. Sękowska, Kształcenie dzieci niewidomych, Wydawnictwo PWN, Warszawa 1974 , s. $175-183$. 
pewne substytuty tych treści poglądowych, które ludziom niewidzącym, w zupełności lub częściowo są niedostępne, a odgrywają ważną rolę w kształtowaniu ich świata wyobrażeń i pojęć ${ }^{8}$.

Analogia pozwala na łączenie ze sobą wrażeń, na szukaniu cech wspólnych. Taka aktywność poznawcza wzbogaca wiedzę, rozszerza zakres wyobrażeń surogatowych, które stają się w ten sposób wielomodalnymi.

Aby niewidomi mogli dokonywać analogii, potrzebna jest umiejętność tworzenia określonych reprezentacji umysłowych, które powstają w wyniku złożonego procesu poznawczego bazującego na wrażeniach pochodzących z różnych źródeł: z kanałów sensorycznych (dotykowych, słuchowych, czuciowych), a także z wrażeń przestrzennych ${ }^{9}$. Wrażenia te transportowane są następnie do pamięci roboczej, gdzie poddawane są dalszej obróbce. Zdaniem Serge'a Bouaziz, Sandrine Russier i Annie Magnan ${ }^{10}$; Cesara Cornoldi, Marii-Chiary Fastame i Tomaso Vecchi11; Mortona A. Hellera oraz Edouarda Gentaza ${ }^{12}$ niewidzenie o charakterze wrodzonym nie ogranicza powstawania obrazów mentalnych, lecz są one uboższe $\mathrm{w}$ informacje i wolniej powstają niż w przypadku osób posługujących się wzrokiem.

Do tworzenia analogii geometrycznych potrzebna jest umiejętność dokonywania rotacji. Aby jej dokonywać, potrzebny jest punkt odniesienia wobec którego będzie dokonywać się rotowanie. Dlatego też zdaniem Anny Sfard wartościowe jest wykorzystywanie

${ }^{8}$ M. Grzegorzewska, Struktura wyobrażeń surogatowych u niewidomych, „Polskie Archiwum Psychologii” 1927, t. 1, 4, s. 302.

${ }^{9}$ C. Cornoldi, M.-C. Fastame, T. Vecchi, Congenitally blindness and spatial mental imagery, [w:] Touching for Knowing, red. Y. Hatwell, A. Streri, E. Gentaz, John Benjamins Publishing Company, Amsterdam/Philadelphia 2003, vol. 53, s. 173-187.

10 S. Bouaziz, S., Russier, A. Magnan, The Copying of Complex Geometric Drawings by Sighted and Visully Impaired Children, "Journal of Visual Impairment and Blindness" 2005, vol. 99(12), s. 765-774.

11 C. Cornoldi, M.-C. Fastame, T. Vecchi, op. cit.

12 M.A. Heller, E. Gentez, Psychology of Touch and Blindness, "Psychology Press 2014, New York, s. 132-149. 
w procesie uczenia przedmiotów ścisłych różnych ram, w których można obracać obiekty, przedmioty, rysunki, tworzyć wykresy i schematy ${ }^{13}$. Z kolei Brigotte Röder i Frank Rösler ${ }^{14}$ stwierdzili, że tworzenie zrotowanych obiektów w wyobraźni niewidomych powstaje wolniej i zawiera więcej błędów niż w przypadku osób widzących.

Badania dotyczące wykorzystywania analogii w grupie uczniów niewidomych, a także tworzenia reprezentacji przestrzennych były prowadzone przez Marcusa Kanuff i Elisabeth May ${ }^{15}$. Przeprowadzili oni trzy grupy eksperymentów, w których osoby niewidome i osoby widzące (z zawiązanymi oczami) wykonywały te same zadania. Dotyczyły one określania relacji wzrokowo-przestrzennych, które są łatwe do rozwiązania zarówno wzrokowo jak i przestrzennie; relacji wizualnych, które można łatwo rozwiązać wizualnie oraz zadań trudnych, w których nie da się łatwo przewidzieć rozwiązania zarówno wizualnie, jak i przestrzennie. Okazało się, że niewidomi niezależnie od typu zadania wykonywali je wolniej i mniej dokładnie. Autorzy uważają też, że jeśli wnioskowanie dotyczące relacji przestrzennych opiera się także o informacje słowne, sam proces rozumowanie przebiega sprawniej i jest poprawniejszy.

Rozumowanie przez analogie odgrywa ogromną rolę w życiu osób niewidomych. Umożliwia poznawanie zjawisk, które nie są dostępne niewidomym za pomocą dotyku i słuchu. Ponieważ osoby widzące posługują się słownictwem i wyrażeniami ujmującymi relacje pomiędzy wszystkimi zmysłami - niewidomi muszą w jak najlepszy dla siebie sposób poznać te wyrażenia. Umożliwia im to

${ }^{13}$ A. Sfard, Balancing the unbalancable: The NCTM Standards in Light of Theories of Learning Mathematics, [w:] A research companion to principles and standards for school mathematics, red. J. Kilpatrick, W.G. Martin, D. Schifter, National Council for Teachers of Mathematics, Reston, Virginia 2003, s. 353-392.

${ }^{14}$ B. Röder, F. Rösler, Visual input does not facilitate the scanning of spatial images, “Journal of Mental Imagery" 1998, vol. 22(3-4), s. 165-182.

${ }^{15}$ M. Knauff, E. May, Mental Imagery, Reasoning, and Blindness, “The Quarterly Journal of Experimetal Psychology" 2006, vol. 59(1), s. 161-177. 
właśnie analogia. Rozumowanie przez analogie umożliwia poznawanie określonych relacji pomiędzy przedmiotami, pojęciami, zjawiskami, poszerza zakres słownictwa, zwiększa liczbę rozumianych zagadnień, dzięki czemu tworzona wizja rzeczywistości jest adekwatniejsza.

\section{Założenia metodologiczne}

Celem artykułu jest określenie, w jaki sposób rozumowanie przez analogie geometryczne kształtuje się w trzech grupach wiekowych uczniów niewidomych i widzących (10, 12 i 14 lat). Na podstawie literatury dotyczącej pedagogiki specjalnej i psychologii oraz własnych doświadczeń sformułowano następujące pytania badawcze, które poddano weryfikacji, stosując właściwie dobrane narzędzia pomiaru:

1) Jakie jest rozumowanie przez analogie geometryczne u uczniów niewidomych w III i V klasie szkoły podstawowej oraz I klasie gimnazjum?

2) Jakie jest rozumowanie przez analogie geometryczne u uczniów niewidomych w porównaniu do uczniów widzących w III i V klasie szkoły podstawowej oraz I klasie gimnazjum?

Badania na temat analogii opartych na materiale figuralnym zostały przeprowadzone m.in. przez Bogdana Pietrulewicza ${ }^{16}$. Wykazał on, że w zakresie percepcji dotykowej uczniów niewidomych i widzących w klasie III, V szkoły podstawowej i I gimnazjum, odnoszącej się do analogii opartych na materiale obrazkowo figuralnym, nie ma istotnych statystycznie różnic. Natomiast w zakresie percepcji dotykowej i wzrokowej uczniów widzących istnieją istotne statystycznie różnice niezależnie od wieku badanych (10, 12 i 14 lat). Ponadto badania B. Pietrulewicza17 wykazały, że nie ma istotnych

16 B. Pietrulewicz, op. cit., s. 82-95.

17 Ibidem. 
statystycznie różnic w zakresie percepcji dotykowej niewidomych i percepcji wzrokowej widzących. Zatem zakłada się, że niewidomi równie trafnie jak widzący będą ujmować relacje analogii opartych na materiale figuralnym.

\section{Charakterystyka osób badanych}

Badaniami objęto 126 uczniów ${ }^{18}$. Grupę podstawową stanowiło 63 uczniów niewidomych w wieku 10 lat (III klasa szkoły podstawowej), 12 lat (V klasa szkoły podstawowej) i 14 lat (I klasa gimnazjum). Podzielono ich na trzy kategorie wiekowe liczące po 21 osób. Uczniowie niewidomi pochodzili z całej Polski i uczyli się w 7 specjalnych ośrodkach szkolno-wychowawczych, dlatego też dobór do grupy był celowy. Grupa uczniów niewidomych pod względem płci była jest równoliczna - chłopców było 25, a dziewcząt 38. Wśród 21 badanych trzecioklasistów - $9(42,9 \%)$ przebywało w internacie od 4 lat, czyli od rozpoczęcia nauki w klasie „, 0 ”, 2 osoby $(9,5 \%)$ przebywały 3 lata, 7 osób (33,3\%) - 2 lata, 2 osoby (9,5\%) - 1 rok. W klasie V 4 osoby (19\%) były mieszkańcami ośrodka od 6 roku życia, 7 (33,3\%) - od I klasy, 1 (4,8\%) - od II klasy, 5 (23,8\%) - od III klasy, 2 (9,5\%) - od IV klasy, 2 osoby (9,5\%) nie mieszkały w ośrodku nigdy. Wśród gimnazjalistów 8 uczniów (38,1\%) przebywało w ośrodku 7 lat, czyli od I klasy, 6 (28,6\%) - od 6 lat, 3 (14,2\%) - od 5 lat, $1(4,8 \%)$ - od 4 lat, 1 (4,8\%) - od roku, dwoje mieszkało poza ośrodkiem.

Grupę porównawczą stanowiło 63 uczniów widzących podzielonych na takie same grupy wiekowe i liczbowe. Dobór do grupy porównawczej był celowo losowy, ponieważ dobrano ją pod względem liczebności, płci, klasy i miejsca zamieszkania w odniesieniu do uczniów niewidomych.

18 Badania zostały przeprowadzone w roku szkolnym 2007/2008 i stanowią fragment badań zrealizowanych $\mathrm{w}$ ramach rozprawy doktorskiej. W Polsce od tego czasu nie podejmowano badań na temat analogii geometrycznych. 
Przy doborze osób do grupy przestrzegano wyznaczonych uprzednio kryteriów: istnienie lub brak uszkodzenia wzroku (w przypadku uczniów z uszkodzonym wzrokiem grupę badawczą stanowią osoby niewidome od urodzenia bądź też te, które utraciły wzrok przed piątym rokiem życia); wiek (10; 12 i 14 lat); stwierdzony prawidłowy rozwój intelektualny; typ szkoły (specjalny ośrodek szkolno-wychowawczy dla uczniów niewidomych; szkoła ogólnodostępna dla uczniów widzących); brak dodatkowych schorzeń.

W poniższym artykule zostaną zaprezentowane wyniki badań $\mathrm{w}$ zakresie analogii opartych na materiale obrazkowo figuralnym. W celu zbadania rozumowania przez analogie geometryczne wykorzystano „12 tablic serii B Progressive Matrices” Johna C. Ravena. Wybrano tylko serię B Maryc, gdyż opiera się na zasadzie analogii między parami figur, co zgodne jest $\mathrm{z}$ postawionymi celami badawczymi. Uczniowie widzący rozwiązywali obrazkową wersję w oryginale, natomiast uczniowie niewidomi otrzymali tablice przekształcone na wersję dotykową.

Seria B 12 Matryc Johna C. Ravena została skonstruowana na zasadzie analogii zachodzącej pomiędzy dwiema parami figur. Zadaniem ucznia jest wykrycie relacji, jaka zachodzi pomiędzy parą figur i przeniesienie tej relacji na drugą parę, składającą się z jednego elementu podanego i niewiadomej, która powinna być wybrana na podstawie analogii z sześciu podanych wycinków. Figury można obracać wokół osi poziomej lub pionowej. Kształty figur w zadaniach $B_{1}, B_{9}, B_{10}, B_{11}, B_{12}$ sa punktowo symetryczne, a w zadaniach $B_{2}, B_{3}, B_{4}, B_{5}, B_{6}, B_{7}, B_{8}$ mają charakter punktowo asymetryczny. Figury punktowo symetryczne po obrocie wokół osi nie zmieniaja położenia, punktowo asymetryczne natomiast zmieniają położenie.

\section{Wyniki badań}

Analiza statystyczna danych uzyskanych dzięki zastosowaniu 12 tablic serii B Progressive Matrices J.C. Ravena pozwoliła określić, jakie wyniki w zakresie analogii geometrycznych otrzymują zarów- 
no uczniowie niewidomi, jak i widzący w wieku 10, 12 i 14 lat, uczący się na tych samych szczeblach edukacyjnych (zob. tabela 1).

Tabela 1. Różnice w średnich dla zmiennej analogie geometryczne uczniów z niewidomych i widzących

\begin{tabular}{|c|c|c|c|c|c|c|c|c|}
\hline \multirow{2}{*}{ Zmienna } & $\begin{array}{c}\text { Wiek } \\
\text { badanych }\end{array}$ & \begin{tabular}{c} 
Z $\begin{array}{c}\text { Uczniowie } \\
\text { niewidomi } \\
(\mathrm{N}=63)\end{array}$ \\
\cline { 3 - 9 }
\end{tabular} & $\begin{array}{c}\text { Uczniowie } \\
\text { widzący } \\
(\mathrm{N}=63)\end{array}$ & \multicolumn{3}{|c|}{$\begin{array}{c}\text { Wynik testu } \\
\text { t-Studenta }\end{array}$} \\
\hline \multirow{3}{*}{$\begin{array}{l}\text { Analogie geome- } \\
\text { tryczne }\end{array}$} & 10 lat & 4,10 & 1,37 & 6,00 & 2,53 & $-3,032$ & 40 & 0,005 \\
\cline { 2 - 9 } & 12 lat & 7,76 & 2,30 & 8,48 & 1,81 & $-1,119$ & 40 & 0,270 \\
\cline { 2 - 9 } & 14 lat & 9,33 & 1,24 & 10,00 & 1,55 & $-1,540$ & 40 & 0,131 \\
\hline
\end{tabular}

Objaśnienia: M - średnia arytmetyczna, SD - odchylenie standardowe, df - stopnie swobody, p - poziom istotności, pogrubienie czcionki - istotność statystyczna $<0,05$.

Źródło: Analiza własna na podstawie SPSS 24.0

$\mathrm{W}$ zakresie analogii geometrycznych uczniowie mieli do rozwiązania 12 prób. Za każde prawidłowo rozwiązane zadanie otrzymywali punkt. Maksymalnie mogli otrzymać 12 punktów, a minimalnie 0 . Najwyższą średnią wartość w zakresie analogii geometrycznych osiągnęli uczniowie niewidomi uczęszczający do I klasy gimnazjum (14 lat), wyniosła ona $M=9,33$, co stanowi $77,75 \%$ wyniku maksymalnego możliwego do uzyskania (uczniowie widzący osiągnęli średni wynik $M=10$ ). Wyniki odchylają się o 1,23, a przedział dla średnich wyników mieści się w granicach od 8,10 do 10,56 . Wynik minimalny osiągnięty $\mathrm{w}$ grupie niewidomych 14-latków wyniósł 7 punktów, a maksymalny - 11. Natomiast średnia wartość wyników osiągniętych przez uczniów niewidomych w wieku 10 lat wyniosła $M=4,10$, co stanowi $34,16 \%$ wyniku maksymalnego możliwego do uzyskania. Jest to najniższy wynik osiągnięty przez wszystkich niewidomych uczniów. Wyniki odchylają się o 1,37 punktu, a stworzony przez to przedział średnich wyników wynosi od 2,73 do 5,47. W grupie tej minimalny wynik to 2 punkty, natomiast maksymalny -7 . 
Przeprowadzona analiza ujawniła występowanie jednej istotnej statystycznie różnicy między badanymi grupami uczniów niewidomych i widzących (zob. tabela 1). Na podstawie analizy wartości "t" Studenta wykazano, że $\mathrm{w}$ kwestii rozumowania przez analogie geometryczne istnieje statystycznie istotna różnica między uczniami niewidomymi a widzącymi $\mathrm{w}$ wieku 10 lat, czyli uczącymi się w III klasie szkoły podstawowej $(t=-3,032(40) ; p<0,05)$. Na podstawie wartości średniej arytmetycznej można stwierdzić, że uczniowie widzący $(M=6,00)$ uzyskują istotnie wyższe wyniki w omawianym rodzaju analogii.

Dane liczbowe zawarte $\mathrm{w}$ tabeli 1. pozwalają zauważyć, że nie ma istotnie statystycznych różnic między grupami uczniów niewidomych i widzących w wieku 12 lat (uczących się w V klasie szkoły podstawowej) i w wieku 14 lat (I klasa gimnazjum). Można jedynie stwierdzić na postawie wartości średnich arytmetycznych, że zarówno w jednej $(\mathrm{M}=7,76$ i $\mathrm{M}=9,33)$ jak i drugiej grupie wiekowej $(\mathrm{M}=8,48$ i $\mathrm{M}=10,00)$ uczniowie widzący osiągają lepsze rezultaty $\mathrm{w}$ rozwiązywaniu zadań opartych na materiale geometrycznym.

Otrzymany materiał empiryczny pozwala też zauważyć, że największa dyspersja wyników $\mathrm{w}$ grupie uczniów niewidomych występuje w V klasie szkoły podstawowej (12 lat), a w grupie uczniów widzących - w III klasie szkoły podstawowej (10 lat). Dyspersja ta wraz z wiekiem zmniejsza się. Na podstawie wartości średnich arytmetycznych można zauważyć, że największy przyrost wyników w grupie podstawowej (uczniów niewidomych) oraz porównawczej (uczniów widzących) przypada na okres pomiędzy III a V klasą szkoły podstawowej.

Poniżej przedstawione zostaną dane dotyczące określenia różnic wewnątrzgrupowych za pomocą jednoczynnikowej analizy wariancji (ANOVA) (zob. tabela 2). Wynik F analizy wariancji dla zmiennej analogie geometryczne uczniów niewidomych w wieku 10 lat (III klasa szkoły podstawowej), 12 lat (V klasa szkoły podstawowej) i 14 lat (I klasa gimnazjum) wskazuje na występowanie istotnych statycznie różnic w zakresie badanej zmiennej, co świadczy o zróżnicowaniu wewnątrzgrupowym. 
Tabela 2. Wyniki jednoczynnikowej analizy wariancyjnej ANOVA dla zmiennej wiek w zakresie analogii geometrycznych uczniów niewidomych

\begin{tabular}{|c|c|c|c|c|c|c|}
\hline \multirow[b]{2}{*}{ Zmienna } & \multirow[b]{2}{*}{ Grupa } & \multirow[b]{2}{*}{ M } & \multicolumn{4}{|c|}{ Wyniki analizy wariancyjnej (ANOVA) } \\
\hline & & & $\mathrm{F}$ & grupa & $\begin{array}{l}\text { Różnica } \\
\text { średnich }\end{array}$ & $\mathrm{p}$ \\
\hline \multirow{3}{*}{$\begin{array}{l}\text { Analogie } \\
\text { geometryczne }\end{array}$} & wiek 10 lat & 4,10 & \multirow{3}{*}{$\begin{array}{c}\mathrm{F}=52,235 \\
\mathrm{df}_{1}=2 \\
\mathrm{df}_{2}=60\end{array}$} & grupa 1 i 2 & $-3,667$ & 0,000 \\
\hline & wiek 12 lat & 7,76 & & grupa 1 i 3 & $-5,238$ & 0,000 \\
\hline & wiek 14 lat & 9,33 & & grupa 2 i 3 & $-1,571$ & 0,029 \\
\hline
\end{tabular}

Objaśnienia: M - średnia arytmetyczna, F - wskaźnik analizy wariancyjnej, p - poziom istotności, pogrubienie czcionki - istotność statystyczna $<0,05 ; \mathrm{df}_{1}, \mathrm{df}_{2}$ - stopnie swobody.

Źródło: Analiza własna na podstawie SPSS 24.0

Analiza danych liczbowych ujawniła na postawie wartości wskaźnika F jednoczynnikowej analizy wariancyjnej (ANOVA), że rozumowanie przez analogie geometryczne jest zróżnicowane wiekiem osób badanych $(F(2 ; 60)=52,235 ; p<0,05 ;$ zob. tabela 2). Celem określenia różnic istotnych statystycznie $\mathrm{w}$ zakresie rozumowania przez analogie geometryczne pomiędzy uczniami niewidomymi w wieku 10, 12 i 14 lat dokonano analizy wyników z uwzględnieniem testu Testu Dunnetta, gdyż wariancje nie były jednorodne. Należy zaznaczyć, że uczniowie w wieku 14 lat (I klasa gimnazjum) charakteryzują się istotnie wyższym średnim wynikiem $(\mathrm{p}<0,005) \mathrm{w}$ porównaniu do uczniów w wieku 12 lat (V klasa szkoły podstawowej; p <0,005) i uczniów w wieku 10 lat (klasy III szkoły podstawowej; $\mathrm{p}<0,05)$. Na podstawie wartości średnich arytmetycznych można dodatkowo stwierdzić, że im większa różnica wieku między uczniami, tym dysproporcje wśród grup uczniów niewidomych są większe.

Z analizy wyników badań wynika również, że uczniów niewidomych w trzech badanych kategoriach wiekowych najłatwiejszymi zadaniami okazały się następujące próby: $1(\mathrm{M}=18,33), 2(\mathrm{M}=17)$, $3(\mathrm{M}=17), 4 \quad(\mathrm{M}=16), 5 \quad(\mathrm{M}=14,33), 6 \quad(\mathrm{M}=13), 7 \quad(\mathrm{M}=10,66)$ i $9(\mathrm{M}=11,33)$. Natomiast trudności przysporzyły zadania: $8(\mathrm{M}=9,66)$, $10(\mathrm{M}=10), 11(\mathrm{M}=6,66), 12(\mathrm{M}=4,31)$. W przypadku uczniów widzących próby, które zostały rozwiązane bezbłędnie to: $1(M=20,66)$, 
$2(M=20,66), 3(M=20,33), 4(M=17,66), 5(M=16,33), 6(M=15)$, $7(\mathrm{M}=13), 9(\mathrm{M}=11,33)$ i $10(\mathrm{M}=11)$. Zadania, które okazały się najtrudniejsze to $8(\mathrm{M}=10), 11(\mathrm{M}=7,66)$ i $12(\mathrm{M}=7,66)$. W żadnym zadaniu uczniowie niewidomi nie osiągnęli wyniku wyższego od uczniów widzących.

Poniżej zadania te zostaną scharakteryzowane w kolejności numerycznej.

Zadanie 1. (dotyczące figury o charakterze symetrycznym) było najłatwiejszym z 12 przedstawionych prób i nie sprawiło zbyt wielu trudności zarówno uczniom niewidomym, jak i widzącym. Jedynie niewidomi trzecioklasiści uzyskali tylko 13 punktów (61,9\%). Prawie wszyscy pozostali odpowiedzieli prawidłowo.

Zadanie 2. zostało skonstruowane na podobnej zasadzie, jak poprzednia próba, lecz miało nieco bardziej złożony charakter (figura o charakterze punktowo asymentrycznym). Największe różnice są widoczne między klasą III (11 punktów - 52,38\%) a V (19 punktów - 90,47\%) w grupie uczniów niewidomych. Różnica ta wynosi aż 8 punktów. W grupie uczniów widzących różnica wynosi tylko 1 punkt. Uczniowie $\mathrm{z}$ obu grup w I klasie gimnazjum otrzymali po 21 punktów (100\%). Typowym błędnym rozwiązaniem podawanym przez uczniów jest wskazywanie figury zbliżonej do prawidłowej, lecz różniącej się wielkością i proporcją poszczególnych elementów (odpowiedzi 2 i 3).

Zadanie 3. dotyczyło figury o charakterze punktowo asymetrycznym. Podstawą jego prawidłowego rozwiązania jest wykrycie relacji przeciwieństwa między parami figur. Rozsiew wyników jest podobny jak w zadaniu 2. Największa różnica wystąpiła między klasą III (11 punktów - 52,38\%) a klasą V (19 punktów - 90,47\%) w grupie uczniów niewidomych. Tak dużych różnic w grupie uczniów widzących nie było. Najwięcej błędnych odpowiedzi udzielanych przez uczniów niewidomych dotyczyło figury 5., ponieważ nie uwzględnili obrotu o $180^{\circ}$. Wskazywali też na figurę 4. (figura o zmiennych cechach) i 2 (figura pomniejszona).

Zadanie 4. dotyczyło figury punktowo asymetrycznej. Jego rozwiązanie zależy od umiejętności dokonania syntezy koła. Różnice 
pomiędzy grupami są coraz widoczniejsze. Uczniowie niewidomi z III klasy osiągnęli wynik 10 punków (47,61\%), a uczniowie widzący $14(66,66 \%)$. Między III a V klasą uczniów niewidomych różnica wyniosła 8 punktów, a w grupie widzących 5. Natomiast między III klasą uczniów niewidomych i widzących wynosi 4 punkty, a między piątoklasistami niewidomymi i widzącymi - 1 punkt. Zarówno uczniowie z uszkodzonym wzrokiem, jak i widzący w I klasie gimnazjum osiągnęli po 20 punktów (95,23\%). Najczęstszymi błędnymi odpowiedziami jest wskazywanie na rozwiązanie 4 i 6 . Są to figury, w których nie uwzględniono rotacji i są powtórzeniem podanych figur głównych. Wybrano także figurę nr 3, czyli taką, która jest pomniejszona.

Zadanie 5. to również figura o charakterze punktowo asymetrycznym, zmieniająca swoje cechy. Osoba badana, aby rozwiązać to zadanie, musiała dokonać rotacji figury oraz uwzględnić zmienioną cechę liniowości powierzchni. Jest to zadanie dość trudne dla uczniów w młodszym wieku szkolnym. W każdej kategorii wiekowej uczniowie widzący uzyskali wyższe wyniki w porównaniu do uczniów z uszkodzonym wzrokiem. Zarówno w grupie podstawowej, jak i porównawczej największe tempo przyrostu wyników przypada na okres między III a V klasą szkoły podstawowej. Najczęstszymi błędami popełnianymi w młodszym wieku szkolnym w obu badanych grupach jest wskazywanie na tablice $\mathrm{nr} 4 \mathrm{i} 5$. Są to figury niezrotowane o $180^{\circ}$. Figura 3. jest tożsamościowa z figurą główną leżącą $w$ dolnym lewym rogu. Figura 5 . jest odzwierciedleniem figury prawej górnej, do której uczeń powinien znaleźć figurę analogiczną.

Zadanie 6 ma charakter punktowo asymetryczny i polegało na rotacji figury o $180^{\circ}$. Największe tempo przyrostu wyników zarówno $\mathrm{w}$ grupie podstawowej, jak i porównawczej przypada na okres między III i V klasą szkoły podstawowej. Różnica wyników w grupie uczniów niewidomych wyniosła 8 punktów, a w grupie uczniów widzących 10 punktów. Natomiast różnice pomiędzy wynikami uzyskanymi między V klasą a I gimnazjum są minimalne i wynoszą odpowiednio 2 i 1 punkt. Charakterystycznymi błędami popełnia- 
nymi przez uczniów z obu badanych grup jest wskazywanie następujących odpowiedzi: 2, 4, 5, 6. Figura 2. jest odpowiednikiem głównej figury w górnej lewej stronie, figura 4 . jest tożsamościowa $\mathrm{z}$ figurą główną leżącą na górnej prawej części strony. Natomiast odpowiedź wskazująca na figury 5. i 6. dotyczy rotacji o $180^{\circ}$, a nie o $90^{\circ}$.

Zadanie 7. także obejmuje figurę o charakterze punktowo asymetrycznym. Stopień trudności tej próby jest duży, gdyż wymaga od ucznia dokonania rotacji o $180^{\circ}$ oraz uwzględnienia liniowości powierzchni, co dla uczniów niewidomych w młodszych klasach nie jest łatwe. Największy przyrost wyników odnośnie tego zadania ponownie przypada na okres między III a V klasą szkoły podstawowej. Różnica wyników między III a V klasą w grupie uczniów niewidomych wyniosła 7 punktów, a w grupie uczniów widzących 8 punktów. Natomiast różnice pomiędzy klasą V a I gimnazjum w grupie uczniów niewidomych wynosi 3 punkty, zaś w grupie uczniów widzących - 1 punkt. W zadaniu tym na wszystkich trzech szczeblach wiekowych lepsze wyniki uzyskali uczniowie widzący. Najczęściej wybierano odpowiedzi nr 2, 3, 4 oraz 6. Figura 2. jest powtórzeniem figury głównej leżącej w prawej górnej części strony. Figura 3. jest obrócona $\mathrm{w}$ osi poziomej i pionowej o $180^{\circ}$, ale nie zawiera cech liniowości. Figura 4 . odwrócona jest o $180^{\circ} \mathrm{w}$ osi poziomej. Natomiast figura 6 . jest zrotowana o $180^{\circ} \mathrm{w}$ osi poziomej i pionowej, ale zawiera cechy liniowości.

Zadanie 8. dotyczy figury o charakterze punktowo asymetrycznym. Jego rozwiązanie zależy od umiejętności wyróżniania figury z tła. Największe tempo przyrostu wyników przypada na okres między III a V klasą. W grupie uczniów niewidomych różnica wyników pomiędzy uczniami uczącymi się w tych klasach wyniosła 5 punktów, a w grupie uczniów widzących -8 punktów. Natomiast różnice pomiędzy uczniami z klasy V i I gimnazjum są minimalne. W tym zadaniu uczniowie widzący ponownie osiągnęli wyższe rezultaty $\mathrm{w}$ porównaniu do swoich niewidomych rówieśników. Błędy dotyczyły następujących figur: 1, 3, 5, 6. Figura 1. jest perseweracją głównej figury leżącej w górnej części lewej strony. Figura 3. odwołuje się do figur głównych umiejscowionych po prawej stronie 
na dole i na górze. Z kolei uczniowie, którzy wybrali na miejsce niewiadomej odpowiedź nr 5, wskazali na figurę, nie uwzględniając zmian jej cech. Figura 6. wprawdzie jest zbliżona do prawidłowej, ale nie identyczna.

Zadanie 9. odnosi się do figury o charakterze punktowo symetrycznym i wymaga rotowania figur. $W$ tym zadaniu podobnie jak w poprzednich, można stwierdzić, że największy rozsiew wyników zarówno w grupie uczniów niewidomych, jak i widzących przypada na okres między III a V klasą szkoły podstawowej. Różnica w uzyskanych wynikach w grupie uczniów niewidomych, wyniosła 5 punktów, natomiast w grupie uczniów widzących - 7 punktów. Z kolei różnice w wynikach pomiędzy $\mathrm{V}$ klasą a I gimnazjum są minimalne. W tym zadaniu uczniowie niewidomi w klasie III w porównaniu do uczniów widzących zdobyli o 1 punkt więcej. Natomiast liczba otrzymanych punktów przez uczniów z grupy podstawowej i porównawczej w I klasie gimnazjum wyniosła po 15 (71,42\%). Nieprawidłowe rozwiązania dotyczą figur: 1, 2, 5, 6. Figura 1. jest perseweracją głównej figury leżącej po prawej górnej stronie. Figura 2. jest wprawdzie powtórzeniem figury głównej do której należy ułożyć analogie, ale uwzględnia zmianę cechy poprzez dodanie elementów. Figura 5. jest perseweracją figury głównej leżącej w lewej dolnej części strony. Natomiast figura 6. uwzględnia cechy figury głównej, ale nie tej, do której należy znaleźć analogie.

Zadanie 10. to zadanie typu punktowo symetrycznego i wymaga od wstawienia dodatkowego elementu. Największy przyrost wyników przypada na okres pomiędzy klasą V a I gimnazjum, gdyż w przypadku uczniów niewidomych różnica ta wynosi 8 punktów, a w przypadku uczniów widzących 12 punktów. Zadanie to dla uczniów niewidomych uczących się w III klasie okazało się bardzo trudne, gdyż uzyskali tylko 4 punkty. W grupie uczniów niewidomych i widzących błędy były podobne. Najwięcej popełnili uczniowie niewidomi z III klasy. Wskazywali oni wszystkie z możliwych odpowiedzi, choć najczęściej - odpowiedzi 1 i 2, które były perseweracjami głównych figur. Rzadziej wybierano figury nr 3, 4, 5 i 6. 
Zadania 11. i 12. mają charakter punktowo symetryczny. Zarówno uczniowie $\mathrm{z}$ grupy podstawowej jak i porównawczej osiągnęli niskie wyniki. W zadaniu 11, które polegało na zmianie położenia figury, uczniowie niewidomi i widzący uczący się w III klasie podali tyko po dwie odpowiedzi poprawne $(9 \%)$. Natomiast w próbie 12. żaden z uczniów niewidomych nie wybrał ani jednej prawidłowej figury. Ani w zadaniu 11., ani w 12. uczniowie niewidomi nie osiągnęli rezultatów wyższych od wyników otrzymanych przez uczniów widzących. Odnośnie do zadania 11. uczniowie wskazali wszystkie z możliwych nieprawidłowych odpowiedzi, choć najwięcej dotyczyło figur: 2, 3 i 6 . Figura 2. odnosiła się do perseweracji figury głównej leżącej w lewej części strony, figura 3. to rotacja figury, do której powinna być ułożona analogia. Natomiast odpowiedzi wskazujące na figurę 6. odnosiły się do perseweracji figury głównej. Najtrudniejsza była próba 12. Podstawą jej poprawnego rozwiązania było odjęcie figur wpisanych $\mathrm{w}$ środku. Najczęstszymi błędami było podawanie odpowiedzi 2 i 3, które odnosiły się do perseweracji figur głównych. Pojawiają się najczęściej, gdyż uczniowie, nie znajdując analogii, powoływali się na te figury, do których musieli się odnieść. Zdecydowanie rzadziej uczniowie podawali odpowiedzi 1 i 4.

\section{Podsumowanie i wnioski}

Reasumując wyniki uzyskane w trakcie badań nad rozumowaniem przez analogie geometryczne, można wysnuć następujące wnioski:

1. Na podstawie analiz statystycznych wykazano, że w kwestii rozumowania przez analogie geometryczne istnieje istotna statystycznie różnica między uczniami niewidomymi a widzącymi w III klasie szkoły podstawowej (10 lat), na korzyść uczniów widzących. Niewidomi piątoklasiści (12 lat) i uczniowie I klasy gimnazjum (14 lat) także uzyskali niższe od widzących rówieśników wyniki, choć nie są to różnice istotne statystycznie. Takie rezultaty można tłumaczyć wolniejszym u niewidomych rozwojem operacji umysło- 
wych, takich jak np. porównywanie. Wraz z wiekiem dyspersja między grupą podstawową i porównawczą zdecydowanie maleje, bowiem uczniowie klas starszych dzięki systematycznym ćwiczeniom dotykowym doskonalą umiejętności różnicowania, klasyfikowania i rotowania elementów. Podobne wnioski wysnuli na podstawie swych badań Bogdan Pietrulewicz ${ }^{19}$ i Krzysztof Klimasiński²0.

2. We wszystkich 12 próbach analogii geometrycznych stwierdzono, że uczniowie niewidomi osiągnęli niższe rezultaty od swych widzących rówieśników. Mogło to wynikać z charakteru materiału, na którym pracowali. Uczniowie widzący rozwiązywali zadania w wersji oryginalnej, a uczniowie niewidomi posługiwali się wersją dotykową, co utrudniało dostrzeżenie różnic pomiędzy poszczególnymi figurami, o czym pisano wcześniej.

3. Najtrudniejszymi okazały się próby o charakterze punktowo symetrycznym, wymagające zmiany położenia figury i odjęcia figur wpisanych w środku. Najczęstsze błędy popełniane zarówno przez uczniów niewidomych, jak i widzących były następujące: perseweracje figur głównych, błędna rotacja, wybieranie figur podobnych, lecz różniących się wielkością i proporcją poszczególnych elementów, nieuwzględnianie cech liniowości. W obydwóch grupach miały podobny charakter, ale niewidomi popełnili ich znacznie więcej.

Rozumowanie przez analogie to jeden z podstawowych sposobów wzbogacania i pogłębiania wiedzy. Jest ono tym doskonalsze, im uczniowie niewidomi mają więcej sposobów do wykorzystywania go w praktyce. $W$ tym celu nauczyciele powinni zadbać o przygotowywanie różnych zadań o charakterze analitycznym, syntetycznym i analityczno-syntetycznym.

Nauczyciele powinni również pamiętać, aby podczas zajęć nie tylko z przedmiotów ścisłych uczniowie mogli dokonywać porównywania, abstrahowania, mogli rotować i zmieniać położenie

19 Ibidem.

${ }^{20}$ K. Klimasiński, Rola wyobrażeń przestrzennych w rozwoju myślenia dzieci niewidomych, Wydawnictwo PAN, Zakład Narodowy Ossolińskich, Wrocław-WarszawaKraków-Gdańsk 1977, s. 47-89. 
przedmiotów. Aby zwiększyć jakość analogii geometrycznych, potrzeba jest jak największej ilości ćwiczeń sensorycznych, bazujących na zmyśle dotyku i słuchu oraz z zakresu orientacji przestrzennej.

\section{Bibliografia}

Biela A., Psychologiczne podstawy wnioskowania przez analogie, Wydawnictwo PWN, Warszawa, 1989.

Bouaziz S., Russier S. Magnan A., The Copying of Complex Geometric Drawings by Sighted and Visully Impaired Children, "Journal of Visual Impairment and Blindness" 2005, vol. 99(12).

Chlewiński Z., Falkowski A., Francuz P., Wnioskowanie przez analogię w procesach kategoryzacji, Wydawnictwo Towarzystwo Naukowe KUL, Lublin 1995.

Cornoldi C., Fastame M.-C., Vecchi T., Congenitally blindness and spatial mental imagery, [in:] Touching for Knowing, red. Y. Hatwell, A. Streri, E. Gentaz, John Benjamins Publishing Company, Amsterdam/Philadelphia 2003.

Grzegorzewska M., Struktura wyobrażeń surogatowych u niewidomych, „Polskie Archiwum Psychologii" 1927, t. 1, 4.

Heller M.A., Gentez E., Psychology of Touch and Blindness, Psychology Press, New York 2014.

Klimasiński K., Rola wyobrażeń przestrzennych w rozwoju myślenia dzieci niewidomych, Wydawnictwo PAN, Zakład Narodowy Ossolińskich, Wrocław-WarszawaKraków-Gdańsk 1977.

Knauff M., May E., Mental Imagery, Reasoning, and Blindness, "The Quarterly Journal of Experimetal Psychology" 2006, vol. 59(1).

Kwiatkowski T., Logika ogólna, Wydawnictwo UMCS, Lublin 1992.

Nęcka E., Orzechowski J., Szymura B., Psychologia poznawcza, Wydawnictwo Naukowe PWN, Warszawa, 2006.

Pietrulewicz B., Rozwój rozumowanie przez analogię u dzieci niewidomych, Wydawnictwo PAN, Komitet Nauk Psychologicznych, Zakład Narodowy Ossolińskich, Wrocław, Kraków, Gdańsk, Łódź 1983.

Przybyłowski J., O pewnej interpretacji wnioskowania przez analogie, [w:] Logiczne podstawy rozumowań, cz. II, red. L. Kostro, J. Przybyłowski, Wydawnictwo, Uniwersytet Gdański, Gdańsk 1997.

Röder B., Rösler F., Visual input does not facilitate the scanning of spatial images, "Journal of Mental Imagery" 1998, vol. 22(3-4).

Sękowska Z., Kształcenie dzieci niewidomych, Wydawnictwo PWN, Warszawa 1974.

Sfard A., Balancing the unbalancable: The NCTM Standards in Light of Theories of Learning Mathematics, [w:] A research companion to principles and standards for school mathematics, red. J. Kilpatrick, W.G. Martin, D. Schifter, National Council for Teachers of Mathematics, Reston, Virginia 2003. 